\section{SOI: 1.1/TAS DOI: 10.15863/TAS International Scientific Journal Theoretical \& Applied Science}

\author{
p-ISSN: 2308-4944 (print) e-ISSN: 2409-0085 (online) \\ Year: $2016 \quad$ Issue: 2 Volume: 34 \\ Published: 29.02.2016 http://T-Science.org
}

Piraga E. Ismailzade

leading researcher, doctor of philosophy in history, Institute of Archaeology and Ethnography, NAS of Azerbaijan piragaismailzade@gmail.com

SECTION 13. Geography. History. Oceanology. Meteorology.

\title{
ON ETHNO-CULTURAL CONTACT OF RUSSIAN AND TURKIC PEOPLES PUBLIC DOMESTIC
}

Abstract: Ethno-cultural contacts, is the problem of cultural interaction between two or more nations, developing on the basis of historical Russian-Turkish relations. Social, political, natural - geographic conditions is another, equally important in the development of Russian-Turkish ethno-cultural contacts. In Turkic languages this term is understood genus of linen and cotton fabrics.

Key words: ethnic culture, nation, relationship.

Language: Russian

Citation: Ismailzade PE (2016) ON ETHNO-CULTURAL CONTACT OF RUSSIAN AND TURKIC PEOPLES PUBLIC DOMESTIC. ISJ Theoretical \& Applied Science, 02 (34): 32-35.

Soi: http://s-o-i.org/1.1/TAS-02-34-5 Doi: crossef http://dx.doi.org/10.15863/TAS.2016.02.34.5

\section{ОБ ЭТНОКУЛЬТУРНЫХ КОНТАКТАХ РУССКОГО И ТЮРКСКИХ НАРОДОВ В ОБЩЕСТВЕННОМ БЫТУ}

Аннотация: Этнокультурные контакты, это проблема культурного взаимодействия между двумя или большего числа народностей, развиваюшихся на основе исторических российско-турецких отношений. Сочиальные, политические, природно - географические условия - это другой, не менее важный в развитии российско-туреиких этнокультурных контактов. В тюркских языках этот термин понимается как род льняных и хлопчатобумажных тканей.

Ключевые слова: этнокультура, народность, отношения.

Этнокультурные контакты, это проблема культурного взаимодействия двух или большего числа народностей, развивающихся на основе исторически возникающих социально экономических связей. Действительно, несмотря на определенные успехи в изучении названной проблемы, этнокультурные контакты еще не стали объектом специальных теоретических разработок. До сих пор этнографическая наука почти не располагает конкретными региональными исследованиями по этой проблеме, что предельно сужает фактологическую базу обобщений. Тюрковедение в этом плане не составляет исключения, хотя русские материалы крайне важны и ценны для общей характеристики этнокультурных контактов. Восточная Европа всегда был регионом интенсивных контактов, что обусловливалось её географическим положением, историческими условиям, большой полиэтничностью.
Этнокультурные контакты, прямое или косвенное взаимодействие этнических культур, могут развиваться практически во всех сферах культуры контактирующих этносов и иметь множество форм, видов, подвидов. Сейчас же, предварительно, представляя этнокультурные контакты как единый тип, в нем можно выделить некоторые формы контактов, такие как хозяйственные, социальные, политические, бытовые (1; с.159). Например, политические этнокультурные контакты русского и тюркских народов начинаются с монголо - татарского завоевания. Эти завоевания привели к созданию Чингизидских государственных образований, к установлению нового международного порядка при котором, сохранялась региональная форма управления при контроле со стороны завоевателей. Это называется конгламератизмом.

Роль и место Золотой Орды возрастает в международной жизни второй половины XIVначала XV в.в. Военная мощь позволяла 
Джучидам диктовать свои условия внешнему миру. По территории Золотой Орды проходили важнейшие торговые маршруты, связывающие русских с восточными народами. В сферу военных, политико - экономических и культурных связей и интересов татарских правителей оказались вовлечены многие народы Евразии. Запад для татарской внешней политики всегда был второстепенным (2; с. 95). По завещанию Чингиз хана Джучидам должны были принадлежать все земли Дешт - и- Кыпчага от границ Каялыка до отдаленнейших мест Саксина, Хазара, Булгара, «вплоть до тех мест, куда достигнет копыто татарской лошади». Ал Омари сообщал, что по завещанию Чингиз хана к Улусу Джучи должны были быть присоединены Арран, Тебриз, Хамадан и Марага. Он указал, что Дербент и Баку с областью Ширван входят в состав Улуса Джучи (2: с.96). Все эти территории находятся на сети торговых путей, в том числе товаров общественного быта. Бытовая культура контактирующих этносов обогащается отдельными заимствованиями в виде элементов или даже целых комплексов в сфере хозяйственного и материального быта, духовной культуры, общественно - семейного быта, норм, традиционных воззрений. Постоянное и длительное общение этносов, способствует формированию в рамках историко - культурного региона во многом единой культурной общности. Общая этническая граница, по которой между соседними этносами развивались интенсивные хозяйственные связи - необходимая основа всех этнокультурных контактов.

Социальные, политические, природно географические условия составляли другую, столь же важную в развитии этнокультурных контактов группу факторов. Между прочим, обилие в горах мест, удобных для обороны, способствовало длительному сохранению там целого ряда независимых политических образований крошечного масштаба. В то же время потребность тюркских народов в зимних пастбищах, расположенных на равнине, и нехватка у горцев хлеба, который можно было выменять у равнинных жителей на продукцию своего животноводства и ремесла, создавали условия для включения многих горных территорий в состав государств, возникавших на соседних равнинах: Византии, Хазарского каганата, Золотой орды. Еще до завоевания Руси, имелись отношения монголо - татарских племен с русскими через кипчаков, ногайцев и других тюркских народов Великой степи.

В эпоху царствованию сына Ивана Грозного Василия III, Московское княжество находилось в состоянии войны с Крымским ханством и Сигизмундом Польским. Опасность нашествия с Востока заставила Великого Князя согласиться с завоеванием Сигизмундом Западнорусских земель. Хотя Иван Грозный и захватил Казанское ханство, последняя никак ни хотела смириться. Когда царь Иван был при смерти казанский хан Магомет Аминь вторгся в Нижгород. Сменивший его на престоле сын Василий поставил перед собой цель завершить дело отца и смирить Казанское ханство. Он принудил хана Магомед Аминя раскаяться в своем поступке и принять свою зависимость. Около 15 лет казанцы (в некоторых русских источниках этот термин используется как обозначающий население Казанского ханства, то есть по территориальной принадлежности, хотя этнически это татары) были смирны. После смерти хана, его окружение попросило от Русского царя нового хана. ОН назначил им ханом юного Ших Али, который рос и воспитывался в Москве, и был внуком последнего хана Золотой Орды Ахмета, и тем самым естественным врагом Крымского хана, который представлял опасность. Магомет Гирей с целью посадить на престол своего брата Саипа подстрекал казанцев, и те в свою очередь свергнули Ших Али и признали ханом последнего. Новый хан не желал подчиниться князю Василию, истреблял русских купцов и посланников, вместе с братом совершил набег на Москву. При первой же возможности, воспользовавшись передышкой в войне с Крымом, князь Василий напал на Казань с целью свергнуть неугодного ему хана. Саип сбежал в Крым, но и народ не принял Ших Али, а требовал себе ханом племенника Саипа, Сафа Гирея. Князь не хотел принять требований казанцев и вновь двинул войска на Казань. В итоге Сафа Гирей тоже сбежал. Казанцы были вынуждены смириться, и князь назначил ханом брата Ших Али, Еналея, который был настолько покорен, что не мог даже жениться без разрешения Москвы. Усмирение Казани отвлекло Василия от главной его цели, - возвращения Западной Руси (3; c.41). Думаем, что эти исторические процессы стали политическим фактором, влияющим на этнокультурные контакты. Но политические условия не являются единственным фактором для возникновения этнокультурных связей. Завоеватели жили на завоеванных территориях, женились на местных женщинах, через 2 - 3 поколения полностью ассимилировались, хотя и сохраняли в устной традиции принадлежность к другой этнической среде. Всё перечисленное способствовало углублению контактов вплоть до бытового уровня, приводило даже к формированию двуязычной и многоязычной среды.

Этнокультурные контакты в области материальной культуры могут быть прослежены с достаточной очевидностью, так как в данном случае о контакте можно судить по фактам 
освоения одной из контактирующих сторон того или иного элемента иноэтнического материального быта. Например, национальная русская одежда чуга имеется и у азербайджанцев. В прикаспийской зоне Азербайджана, в частности на Апшероне, мужскую одежду типа «архалыг» называли дон. Поверх архалыга надевали чуху. Чуха - верхняя ее часть до пояса, а также рукава делали на подкладке из шелка или бумажной материи. Существовали три фасона чухи - со сборками, со складками и с сочетанием сборок и складок. Зимой под чуху надевали короткую стеганую или меховую безрукавки (4: c.126). Н. Костомаров пишет, что русская чуга, это узкий кафтан, с рукавами только по локоть и короче обыкновенных кафтанов, как это видно из кройки, ибо когда кафтан был длиной в два аршина шесть вершков, с рукавами длиной в один аршин пять вершков, чуга для той же особы была длиной в один аршин с тремя четвертями и с рукавами в девять вершков. Чуга попоясывалась поясом, за который закладывался нож и ложка, а на грудь привешивалась перевязь с дорожной сулей (5: с.92). Азербайджанцы иногда по бокам от нагрудника шили газыри (везне) - гнезда для патронов. Так как эта одежда считалась кавалерийской, часто, как и у русских, подол был коротким. Иногда ее назвали «черкези чуха», то есть черкесская чуха.

У Флетчера, при описании русской одежды, она поставлена третьим верхним платьем, первое зипун, второе или среднее узкий кафтан с ножом и ложкою за поясом, третье ферязь - просторное платье, окаймленное позументом. Все, что можно вывести из сбивчивых известий об этом роде одежды - это то, что ферязь - более комнатный род кафтана. Название его тюркское и используется русским народом с XVI века. Оно было в употреблении как у царей, так и у простого народа. На ферязях делались нашивки, называемые образцами.

Одежда называемоя кафтаном также известна тюркским народом, в том числе азербайджанцам. Как писал Н.Кастомаров, национальную мужскую одежду «архалыг», кафтан надевали поверх рубашки, а в холодное время под чуху. Кафтан упоминается в древнетюркском эпосе Деде Коркут под названием «гофтан». В некоторых частях эпоса эта одежда встречается под названием «джубба» или «джубба - дон». Как видим, этот тип одежды был широко распространен в Восточной Европе, Поволжье, На Кавказе, в Передней и Средний Азии. Существуют разные версии по поводу происхождению чухи. По мнению Б. Б. Радлова чуха, чоһа тюркское по происхождению слово и означает сукно (махуд). Е. Т. Тончинская считает, что чуха происходит от длинноподольных мужских халатов из средне вековых восточных миниатюр (6; с. 146 -147).

Кроме кафтана, чуги и ферязей, к разряду средней одежды относились : ормякь, тегиляй, терлик. Терлик была одежда со множеством пуговиц, напр., с шестидесятью- восемью или пятидесятью - шестью. Особенности покроя его неизвестны, как и кофтана. Впрочемь, под последним, кажется, разумели то же, что и под именем чуги, тоест короткое платье, удобное для верховой езды, но он носился также вместо кафтана (6: с.93). Терлик тоже тюркское слово. Происходит от слова «тэр», что означает «пот», переводится как «потник». Кроме того, и сегодня, ткань которая настилается на спину лошади, под седло и контактирует непосредственно с потом лошади называется «терлик».

Верхними или накидными одеждами были епанча и шуба. В свою очередь епанча тоже слово тюркского происхождения. Азербайджанцы поверх «архалыга» надевали чуху, а в холодных предгорных и горных местностях также баранью шубу (кюрк) или бурку (япынджы). В иных случаях иноэтнические инновации, воспринятые народом, сосуществовали с исконными формами. Такие факты особенно заметны в материальной культуре.

Среди импортируемых Русью товаров шелк играл также заметную роль в этнокультурных контактах. Известно, что в Нишапуре, Тебризе, Шеки, Шемахе на экспорт производились не только шерстяные, льняные и хлопчатобумажные ткани (обьярей, залатных бархатов и комки, бейберечиков и др.), обращавшихся на русском рынке в конце XV - XVI вв., очевидно не ранее $\mathrm{XIV}$ в. В общеисторических работах при перечислении товаров, привозимых на Русь с Востока, наряду с шелковыми тканями обычно называется парча в современном понимании этого слова. Подразумевать под «парчой», термином восточного происхождения, парчовую ткань нам кажется сомнительным. В тюркских языках под этим термином понимался род льняных и хлопчатобумажных тканей; применялся он и в значении слова «кусок», «отрезок» и т.д. Продажа восточных тканей на куски наблюдалась и позже, в XVI - XVII в.в. (7; c.143).

Подводя итог должны подчеркнуть что, все выше перечисленные факты свидетельствуют о наличии этнокультурных контактов между русским народом и тюркскими во всех своих проявлениях, в том числе торговых, экономических, политических, культурных, вплоть до семейных и бытовых. 


\begin{tabular}{l|lrl|l|ll} 
& ISRA (India) & $=\mathbf{1 . 3 4 4}$ & SIS (USA) & $=\mathbf{0 . 9 1 2}$ & ICV (Poland) & $=\mathbf{6 . 6 3 0}$ \\
Impact Factor: & ISI (Dubai, UAE) $=\mathbf{0 . 8 2 9}$ & PUHIL (Russia) $=\mathbf{0 . 1 7 9}$ & PIF (India) & $=\mathbf{1 . 9 4 0}$ \\
& GIF (Australia) & $\mathbf{0 . 5 6 4}$ & ESJI (KZ) & $=\mathbf{1 . 0 4 2}$ & & \\
\hline JIF & $=\mathbf{1 . 5 0 0}$ & SJIF (Morocco) $=\mathbf{2 . 0 3 1}$ & & \\
\hline
\end{tabular}

\section{References:}

1. (1989) Kavkazskiy etnograficheskiy sbornik, IX, Voprosy istoricheskoy etnografii Kavkaza, Moscow, «Nauka».

2. Mirgaleev IM (2009) «Zolotoordynskoe gosudarstvo $\mathrm{V}$ sisteme mezhdunarodnykh otnosheniy», Vestnik Chelyabinskogo gosudarstvennogo universiteta, 2009, № 12 (150), Istoriya, Vyp. 31.

3. (1837) Russkaya istoriya, chast' vtoraya, 1462 1689, Sankt-Peterburg.

4. (1962) Narody Kavkaza, ch. II, Moscow.
5. Kostomarov N (1887) Velikorusskogo naroda $\mathrm{V}$ XVI i XVII stoletiyakh starinnye zemskie sobory, S - Peterburg.

6. Mustafaev AN (1977) Material'naya kul'tura Shirvana (na azerbaydzhanskom yazyke), Baku, 1977.

7. Fekhner MV (1981) «K istorii torgovykh svyazey Rusi so stranami vostoka v domongol'skoe vremya», Kavkaz i Srednyaya Aziya v drevnosti i srednevekov'e, «Nauka», Moscow. 